In the ongoing discussion about the relevance of Classical Studies Martin Bernal has challenged quite a few accepted opinions in his book Black Athena; the Afroasiatic roots of classical civilization (London, 1987). From the many provocative statements in this book I choose only a few.

1. The traditions concerning the colonization of Greece by peoples from the East, especially the legends about Kadmos and Danaos, contain a kernel of historical truth.

2. A large part of Greek religion, science and philosophy was derived from Egypt. Herodotos correctly said that the names of nearly all the gods came from Egypt. Plato's Republic was based on Egypt. Of Greek thinkers it can be said: "The deeper they went towards the true Hellenic roots of Greece, the closer they came to Egypt" (p. 108).

3. The ancient Egyptians were black. Although Bernal expresses his doubts concerning the utility of the concept "race" in general, he nevertheless declares: "I believe that Egyptian civilization was fundamentally African ... Furthermore I am convinced that many of the most powerful Egyptian dynasties which were based in Upper Egypt - the 1st, 11th, 12th and 18th - were made up of pharaohs whom one can usefully call black" (p. 242).

4. The study of the Classics, especially Altertumswissenschaft, has always been conservative, supporting the status quo: "... despite its scholarly trappings, its role in the ideological formation of the ruling class has continued to be more important than historical or linguistic enquiry" (p. 288). Philhellenism also had racist tendencies: "But we have seen that Philhellenism has always had Aryanist and racist connotations, and Classics its conservative bias" (p. 387). Therefore the majority of classical scholars have always tried to deny that Asia and Africa had had any worthwhile influence on Greece.

I am not going to discuss the question as to whether these statements are true or false, but wish rather to examine the underlying assumption, namely that a culture is of little worth when it has taken over elements from another culture. Bernal does not say so explicitly, but has great sympathy with the point of view expressed by G.G.M. James in his book, Stolen legacy: the Greeks were not authors of Greek Philosophy, but the people of North Africa, commonly called Egyptians; he describes the theme of this book as "Egyptian cultural achievements stolen by the Greeks" (p. 401). I have even seen press reports in which the Greek legacy is described as the "vomit of African culture".

This attitude is completely mistaken. Although it must be admitted that in the past some classical scholars have tried to prove that the Greeks were completely original in their thought, no scholar today would deny their debt to Egypt and the East. The real achievement of the Greeks is to be found in the way in which they succeeded in combining the elements which they borrowed from the East with their own contributions. In doing so, they created a culture which has played an important role in the history of the world.

Furthermore it is not necessary to maintain that Greek culture was superior to Egyptian culture. What is important is the fact of its immense influence on the cultures of Europe, America and even Africa. This influence may be deplored but cannot be denied. The way in which other nations took over elements of Greek culture and proceeded to adapt and even distort them, remains a fascinating chapter in the history of civilization, and this is one of the main reasons for the continued study of the Classics.

\title{
P.J. Conradie
}

